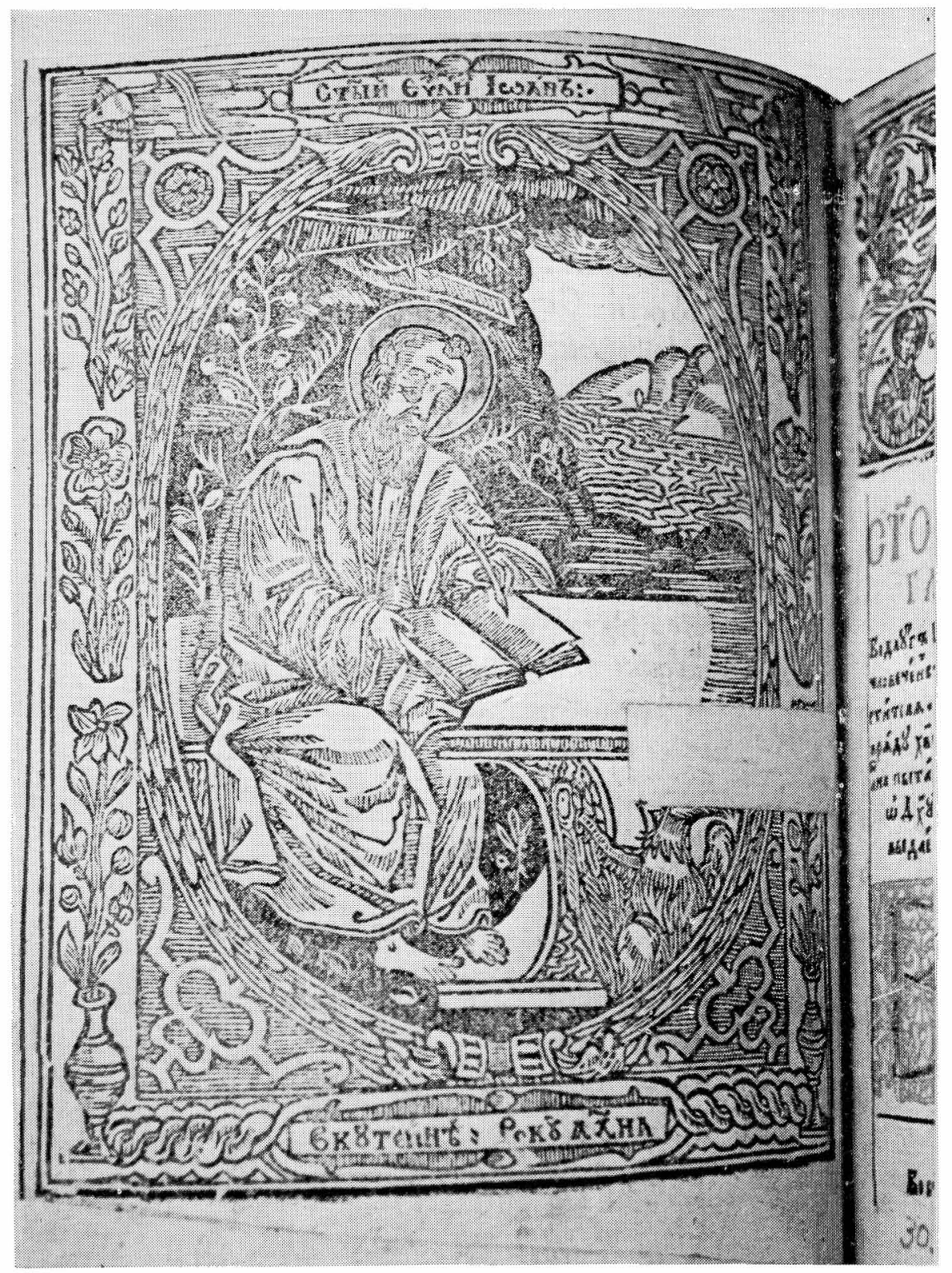

ST. JOHN THE EVANGELIST

(From the Kucieina New Testament and Psalter of 1652) 


\title{
The language of the Kucieina New Testament and Psalter of 1652
}

\author{
BY \\ H. LEEMING
}

The Byelorussian community in London is one of the most active of all immigrant communities. It has added to the amenities of the capital a unique library and museum; it has successfully launched and continues to publish a learned journal of international standing. I am happy to be associated in some small way with these activities as a contributor to the Journal of Byelorussian Studies and to the course in Byelorussian culture.

It was in the Francis Skaryna Library that I was introduced to the book which is the subject of this article. Its title in the original is Novyj zavět Gospoda Našego I[su]s Ch[rist]a, s nemže i psaltyr'. I shall refer to it as the Kucieina New Testament. The bibliographer of Russian Church Slavonic mediaeval publications, I. Karatajev, ${ }^{1}$ tells us that in some copies it bore on the reverse of the title page the coat-of-arms of Michail Stetkevič, a Byelorussian nobleman, with a short poem dedicated to him. There was also a preface by Abbot Ioil' (Joel) Trucevič, dedicating the book to Stetkevič.

The copy in the Francis Skaryna Library is dedicated to another dignitary, namely Bishop Iosif (Joseph) Gorbackij of Viciebsk, Mścisłaŭ, Orša and Mahiloŭ. His coat-of-arms is on the reverse of the title page with a dedicatory poem of four rhyming couplets in syllabic verse, and the book is dedicated to him in a rather fulsome and overblown preface.

The copy is in a good state of preservation and very few pages are damaged. ${ }^{2}$ The first 6 leaves are unnumbered. The Psalter has 126 numbered leaves; the New Testament has 500 numbered in a new sequence. ${ }^{3}$ A previous owner has written in pencil the numbers of the leaves in an unbroken sequence from the beginning to the end.

Each of the gospels is preceded by a woodcut showing the appropriate evangelist at his writing table. Two are shown holding writing implements. Of these one, St. Matthew, is right-handed; St. John, the mystic, is left-handed. We cannot tell whether Mark and Luke were right or left-handed, since they are depicted in an ambidextrous activity - opening, or holding open a book. The book of psalms is preceded by a woodcut of King David. Three of the woodcuts bear 
a date -1651 , that is one year before the publication of the whole book.

From the point of view of the philologist the great interest of the Kucieina New Testament and Psalter lies in the vernacular material contained in the preface, the dedicatory poem, chapter headings and marginal commentary. A complete analysis of this is beyond the scope of the present paper, which is based on a reading of part of the commentary, plus the dedication and preface. Before proceeding to the linguistic discussion it would not be out of place to say something about the Kucieina printing press and about Abbot Joel Trucevič, writer of the preface and publisher of the book.

\section{II}

The history of the Kucieina press seems to begin with the founding of a printing-house in the Podol district of Kiev by Timofej Aleksandrovič in $1625 .{ }^{4}$ This passed into the hands of Spiridon Sobol' who in 1630 moved the press to the Kucieina monastery where he

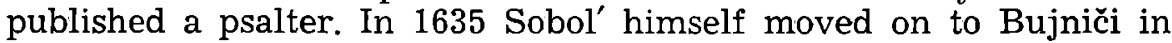
the district of Mahiloŭ and the monks of Kucieina monastery now founded their own press, printing various books, to some of which Abbot Joel contributed prefaces. ${ }^{5}$

The meagre facts concerning Trucevič are given in the standard works of reference. ${ }^{6}$ We are told that he was the founder and abbot of the Kucieina monastery near Orša, and that he opened a school and printing press there. He was favourably disposed, it is said, to the union of Byelorussia and Muscovy. Of his birth and early life nothing is known. We know that he died in 1654 , on his way to the Iverskij Monastery near Valdaj in the Novgorod region, about 260 miles north-north-east of Orša. According to historians of the Russian Orthodox Church Abbot Joel had been invited by Patriarch Nikon to the newly founded monastery but fell ill on the way there. Realising that he would not survive the journey, but eager none the less to respect Nikon's wishes, he asked that his bones should be conveyed without delay to the place his obedient heart yearned for. 'Even in death', he said, 'I will still maintain my obedience to my pastor.' As quoted by the historians, Abbot Joel's last words, as befits such a solemn occasion, were spoken in the Church Slavonic language. ${ }^{7}$

The monastery to which Joel and his brethren had been invited was a new foundation, set up by Nikon in 1653 on the model of the Iverian monastery at Mount Athos. In L. I. Denisov's work describing the orthodox monasteries of Russia, its full title is given as 'Iverskij Bogorodickij Svjatojezerskij Monastyr', in other words the Iverian Monastery of Our Lady at the Holy Lake. ${ }^{8}$ Nikon himself had chosen the site, one of three islands on the Valdaj lake, captivated by its beauty. After Nikon's deposition in 1666 an ecclesiastical court came to the conclusion that the foundation had not been in line with the rules or directives of the holy fathers of the church, whereupon all further building was intermupted, the monks were dispersed among other 
monasteries and even the name of the monastery was deleted (uničtoženo). Two years later some of its rights were restored, and in due course it became a monastery of the first class.

The Kucieina press had been transferred with the brethren to the Iverskij Monastery in 1657. There it had a short working life until, on the closure of the monastery in 1666, it was removed to the Voskresenskij Novyj Ijerusalem monastery, about 40 miles west of Moscow, near Zvenigorod.9

We catch a rare glimpse of Abbot Joel in the journal of Afanasij Filipovič, abbot of Brest, written in 1646.10 Here Afanasij records the help and advice given him by Joel and the deputy abbot, Iosif Surta, when he was attempting to make his way from Pinsk to Moscow. Hearing Afanasij's account of a miraculous sign from Heaven Joel quoted to him the words of St. John of Damascus, that the laws of nature are confounded with the aid of the Blessed Virgin.

But while Joel may have been impressed by Afanasij's story he would not supply him with the letter of recommendation to Moscow which he had requested. Was this because he did not feel he knew Afanasij well enough to recommend him? Was it because of the intervention of some of the other brethren? Afanasij records the fact that Joel conferred with the other monks before refusing him. Or is it possible that this apparent reluctance to help was due to a lack of sympathy for Afanasij's cause? This would cast some doubt on the traditional picture of Joel as a protagonist for the union of Byelorussia and Muscovy.

On advice from Surta, Afanasij attempted to make his way to Moscow via Skłoŭ, Mahiloŭ and Hałoŭčin, after obtaining from Joel letters of recommendation to the senior clergy and the orthodox confraternities. But these documents apparently did not carry much weight, since Afanasij received no help at all. Dispirited he returned to Kucieina monastery to report failure. This time Surta recommended yet another route. Abbot Joel blessed him before his departure and gave him a letter of introduction to Prince Peter Trubeckoj. Perhaps after all it was rather fear of betrayal and retribution that was the cause of Joel's earlier reluctance to help. It had been Afanasij's original intention to travel to Moscow via Smolensk and if such compromising documents had fallen into the hands of the Poles the consequences might have been uncomfortable for Abbot Joel and his brethren.

\section{III}

Examining the Kucieina New Testament from the philologist's point of view we distinguish without difficulty two languages: the traditional Church Slavonic of the biblical text and the East Slavonic of the dedication, prefaces, chapter headings and commentary.

Firstly, a few words might be said about the Church Slavonic text. Not only time but also space intervenes between Old Church Slavonic of 11th-century Bulgaria, Macedonia or Moravia and the Church Slavonic of 17th-century Byelorussia. Characteristics of the East Slavonic dialects have supplanted quite a number of the 
features of the South Slavonic language we call Old Church Slavonic. Even in the earliest surviving East Slavonic book, the Ostromir Gospel-Book, a collection of the readings from the gospels for Sundays and other important days in the church's calendar, features of the scribe's dialect creep into his version of Old Church Slavonic, for example the letters called jusy, originally representing nasal vowels, are confused with $u$ and $j a$. The Church Slavonic of the Kucieina New Testament represents naturally a stage of further divergence. One of the aspects of such innovation which would probably repay further investigation is the position of the stress in numerous words. The following examples were noted. In each case the form met in the Synodal edition of the Church Slavonic Bible is given after that of the Kucieina New Testament: mojégo / mojegó; ugotovájte / ugotóvajte; propovědája / propově́daja; / grěchov / grěchóv; strána / straná; négo / negó; vozljublénnyj / vozljúblennyj; so zvěrmi / so zvěrmí; približisja / priblíżisja..11

\section{IV}

The title page, the dedicatory poem, the two prefaces, the chapter headings and marginal commentary are written, as has been already stated, in the vernacular language of 16th and 17th-century Byelorussia, that is to say in the language spoken by the educated classes. In view of the fact that so many of the linguistic features and much of the vocabulary of this language is common to mediaeval Byelorussian and Ukrainian, scholars have sought to find a satisfactory name for it by reference to its geographical spread: hence zapadnorusskij. Others have used the term 'Ruthenian' to distinguish the western dialects and literary languages of the East Slavonic group from Muscovite or Great Russian. The term has this to be said for it: that it allows us to reserve 'Russian' for sobstvenno russkij or rossijskij. For the purposes of this article I shall refer to the language of the source as Byelorussian, for it originated in Byelorussia and, as we shall see, it has a number of Byelorussian dialectal characteristics.

On the obverse of the title page under the coat-of-arms of Iosif Gorbackij appears a dedicatory poem, which, like other examples of the genre, strives for the heroic and achieves banality.

Ясне свьтятъ клейноты, цныхъ Горбацкихъ дому. Хоть жадного зезнаковъ: горнего триону

Немаютъ: алеже ихъ цале улюбила Отчызна: з неба для нихъ клейноты звабила.

Архиерейска Митра, есть то клейнотъ з неба в гелмъ ю даетъ отчизна: бы южъ не треба

Жадныхъ се штурмовъ земныхъ намнъй варовати самъ $з$ неба Архиерей, хочетъ рятовати.

An approximate rendering of this in English would be:

Bright shine the jewels ${ }^{12}$ of Gorbackij's noble house.

They lack, it's true, the favour of a stellar sign

Above; but since their fatherland has loved them dearly, Wholly; for them from heaven bright jewels has it won. 
A jewel from heaven true is this archbishop's mitre;

Your fatherland confers it as a crest; that we

Need feel no more the least fear of this earth's offensives

While from high Heaven our Archbishop deigns to bring us aid.

While the literary merit of these lines may be doubtful, they are notable for one or two rather unusual expressions. This may be the earliest and possibly the only appearance of the Latinism trion in East Slavonic. ${ }^{13}$ In English poetry of the Elizabethan and Jacobean period the word denotes the constellation of the Great Bear. Thomas Lodge writes:

The fair Triones with their glimmering light,

Smiled at the foot of clear Boötes' wain.

Another writer speaks of the 'heav'ns seven Trions', not perhaps a very elegant phrase, but one which clearly shows that we here have a partial translation of the Latin name for the constellation of the Great Bear, Septentriones, which some etymologists explain as meaning the seven plough-oxen. The Byelorussian poet not only detaches trion from its parent word but extends its semantic field, using it of any constellation. Two things strike us: the writer's extensive acquaintance with the Latin language, and his boldness in the use of Latinisms. We shall see that the same features characterise the language of the dedicatory preface.

\section{$\mathrm{V}$}

The full possibilities of the Ciceronian oratorical style are exploited in the dedication. Statement is ornamented with such loving care and is hedged around with such an intricate filigree of qualification that the main thread of thought is almost lost in the elaborate texture. As I read it for the first time there came to mind a rather irreverent comparison with certain less obscure passages of James Joyce's Finnegan's Wake, where all the words are known, each individual phrase makes its own sense, but the interdependence of the whole is something that remains the property of the writer.

However, an attempt was surely made to convey the meaning of the whole passage to the recipient of the dedication, and one imagines that this was done by a public declamation. The convoluted inter-relationship of the parts could be made clear by a good orator. Repetitions which appear tiresome and pointless on the printed page could be fitted into a melodic and harmonic structure by a speaker trained in the art of rhetoric. Then the repeated words, phrases and themes would develop their counterpoint and balance: the work would become a spoken fugue.

Such a task demands an expert orator, and we may well imagine that Abbot Joel Trucevic had such a man at his disposal, or was himself a distinguished practitioner of the art. We can be sure that rhetoric was known and appreciated, even at a high level, in the monastery of Kucieina. As a proof of this we can take the following fact. Of the fifteen sentences, some of them of inordinate length, which comprise the text of the dedication, no less than five end with a typical Ciceronian cadence: .... .dedykováti podobájet, for example, 


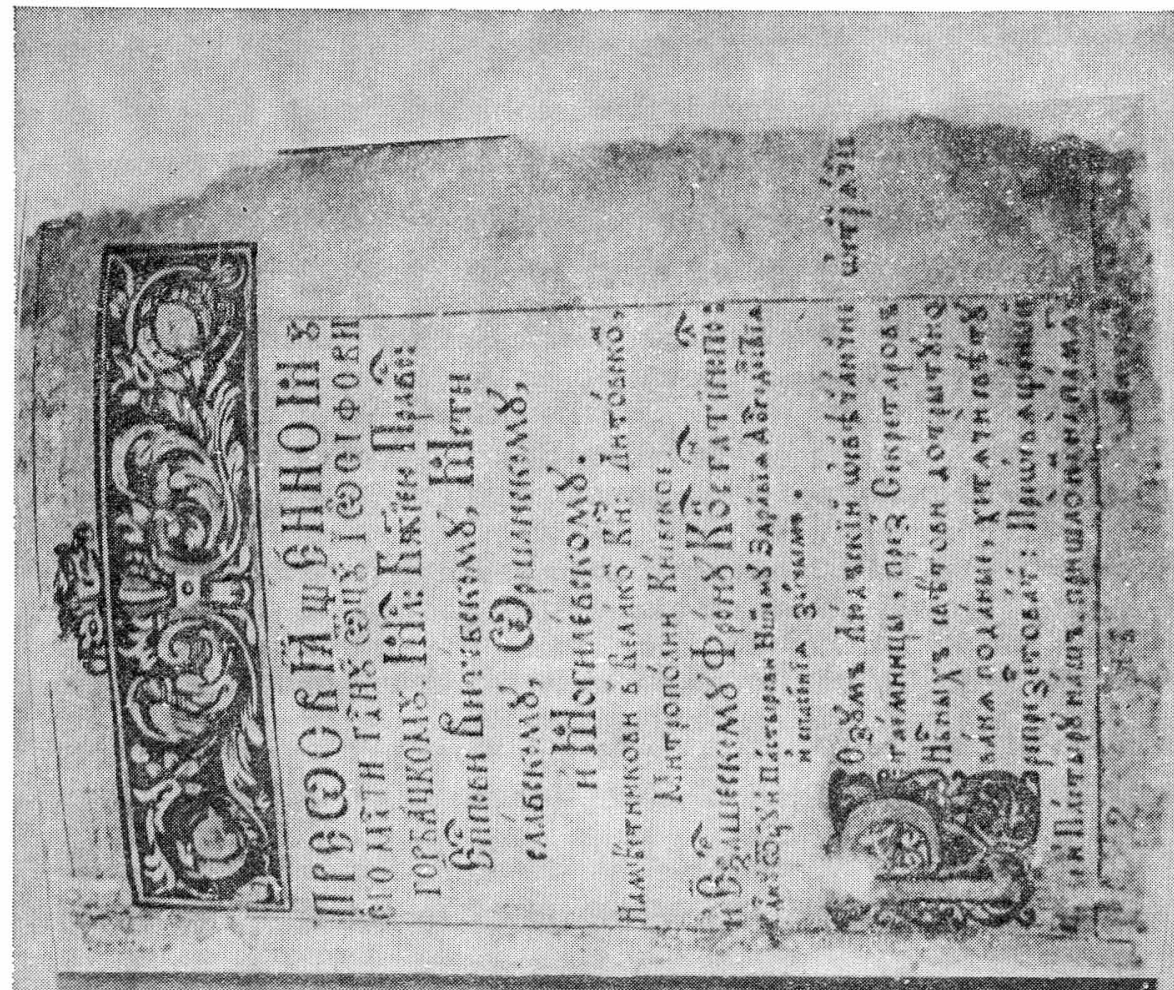

$\frac{2}{0}$

온

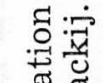

ช

웛

ก่ ชั ช

엄대

压㟧目

का 00

田

봉

Н

थ

ค

是

E

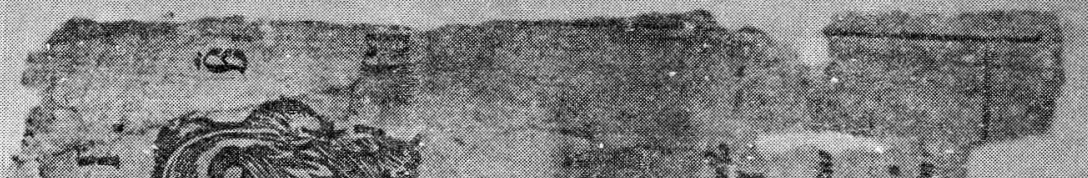

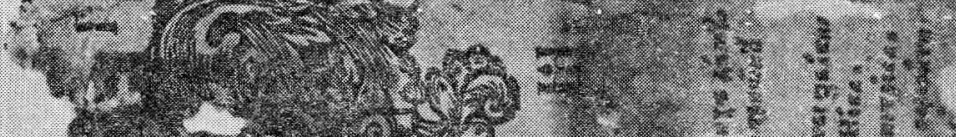

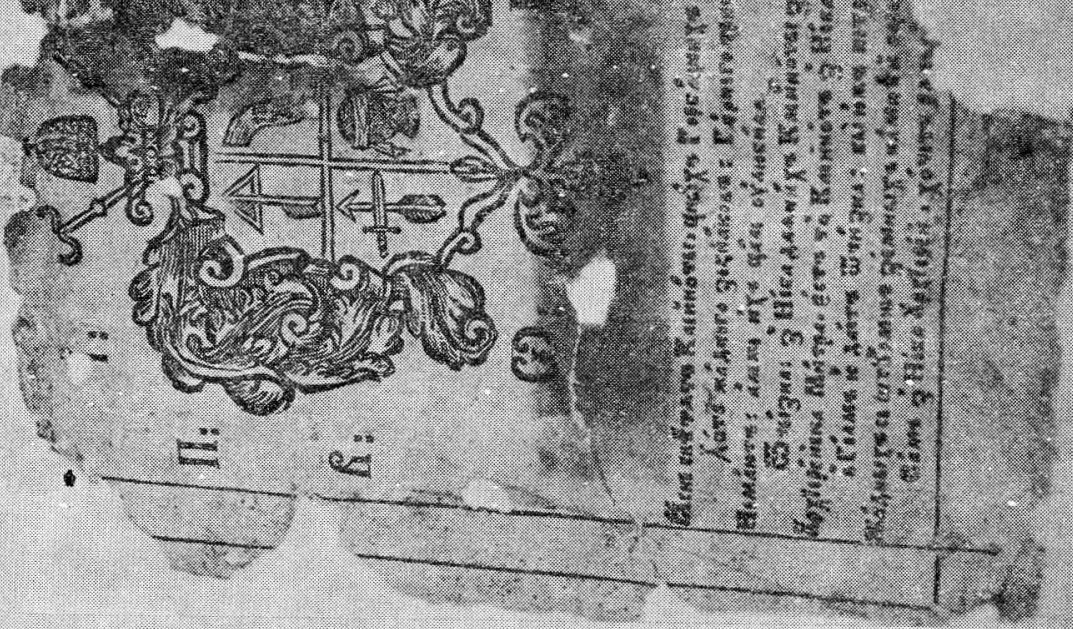


has the same closing rhythm as Cicero's ... esse videatur, a cadence which Quintilian characterised as 'iam nimis frequens' even in his day. ${ }^{14}$ Sheer coincidence could of course produce such a prosodic structure but surely it could not occur in one third of the writer's sentences without at least his acquiescence in what would be an amazing series of such coincidences. There appears to be a case for regarding the Latin influences as not confined to syntax and vocabulary, but even extending to prosody. The full extent of these influences could be determined only by a thorough metrical analysis of the whole text. ${ }^{15}$

\section{VI}

Much of the marginal commentary consists of exegesis of the scriptural text. For example, John the Baptist says to the Pharisees and Sadducees; 'Ye brood of vipers, who hath showed you how to flee from the wrath to come? Bring forth therefore fruit worthy of penance.' The commentary here reads: 'Iž žadnaja pričina (grecha muk věčnych godnogo) bez pokuty, kotoraja $\mathrm{v}$ žitii človečom byti majet, zgoditi ne možet, Ioann Krestitel' ${ }^{\prime}$ opovědajet.'16 In other words, John the Baptist explains that there can be no intercession for a man guilty of mortal sin (sin worthy of eternal torment), unless that man does penance during his life on earth.

The phrase 'Kingdom of Heaven' in the gospel text is elucidated as follows: 'To jest Ch[risto]s krol' pravdivy(j) žydo(v)skyj, kotoryj $\mathrm{v}$ teperešne $(\mathrm{m})$ i $\mathrm{v}$ pryšlom věku kroleva( $t$ ) budet'. ${ }^{17}$ 'Vo dniže ony' - 'in those days' at the beginning of St. Matthew's gospel is explained by the marginal comment: 'za panova(n)ja Tiverija krola'18, that is, in the reign of Tiberius Caesar. A marginal comment on the name of Christ's birthplace points out that this is Bethlehem in Judaea, not Babylonia. ${ }^{19}$

The headings to the psalms explain how they reflect and reinforce Christian doctrine. Thus, the heading to the second psalm, in Latin the 'Quare fremuerunt gentes', reads as follows: 'O poro(ž)ny(ch) umysloch poga(n)skich. I o dare(m)ny(ch) radech $\mathrm{kn}[\mathrm{ja}] \mathrm{zej}$, i pote(n)tatov segosvětni(ch) proti(v) B[og]a, o vytja(ž)stve Ch[risto]vom na(d) nimi, o stalosti žydo(v)skogo nevěrstva. ${ }^{20}$ The psalm is therefore concerned with 'the vain plots of the heathens and the futile plans of the princes and potentates of this world against God, about Christ's victory over them and the continuing perfidy of the Jews'.

The phrase 'o osměj' occurs in the heading to Psalm 6, the first penitential psalm. Modern commentators explain 'for the octave' as meaning 'to be sung to an instrument of eight strings'. Marginal comment in the Kucieina psalter follows St. Augustine who understood the phrase mystically, of the last resurrection and the world to come, the octave being the eighth day, the day of judgment which follows the seven days of mortal life: 'nakonec pě(s)nej o osme(m). to jest o dni sudno(m), above(m) v 7-ch dnjach nede(l)ny(ch) žyvot naš mijaje(t). ožydajučy osmogo dnja, sudu. ${ }^{21}$

Comment may be of other kinds. If a difficult word is felt to be of great significance its translation may be given in the margin. Thus 


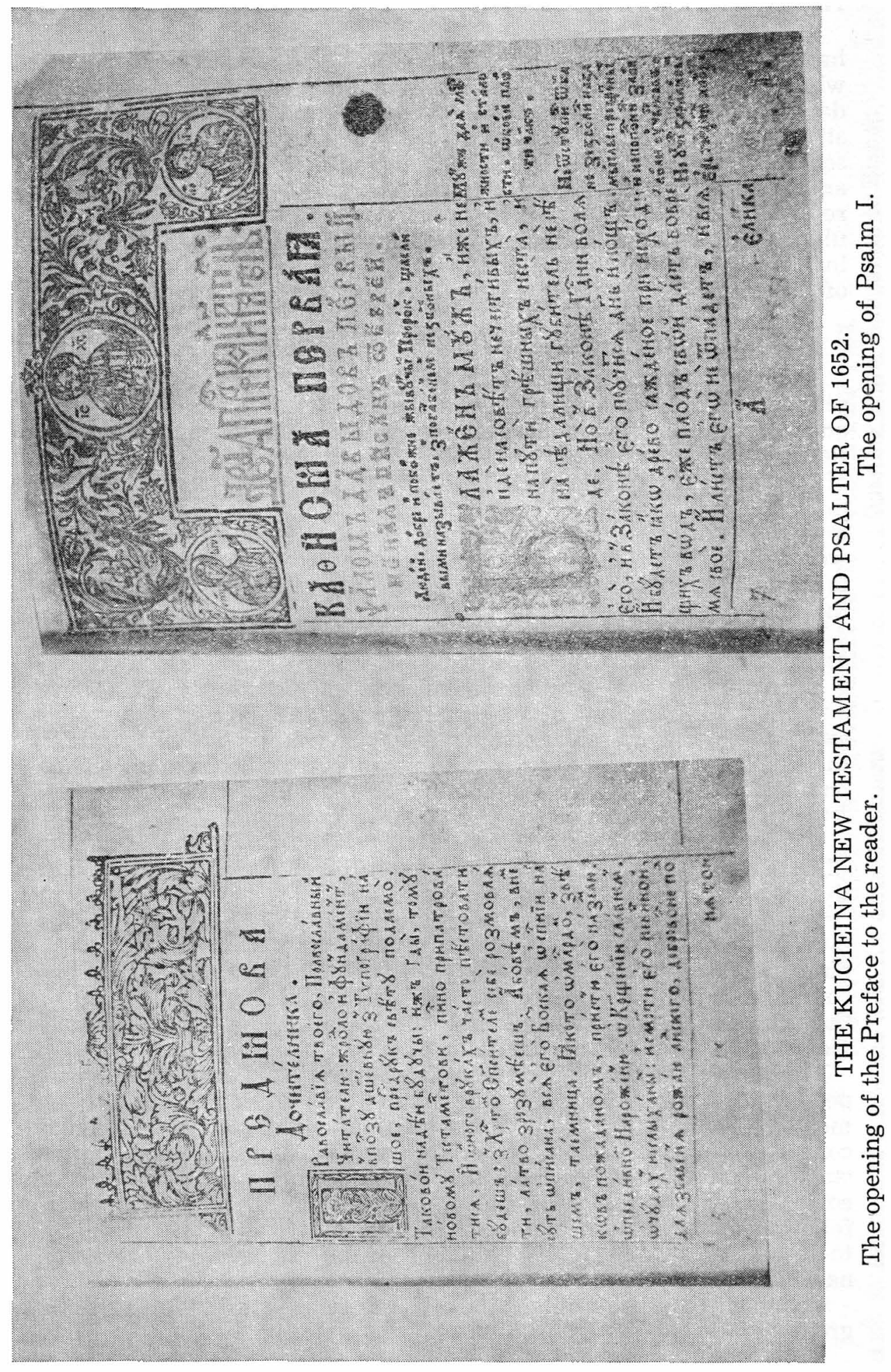


in the genealogy which opens the gospel of St. Matthew the two Hebrew names, Phares and Zara, are explained: 'Fares značy $(t)$ razdelenije, Zara vschoženije', that is, Phares means division, Zara means rising. ${ }^{22}$ Incidentally Pamvo Berynda has both these names in the Onomasticon, or second part of his Lexicon. ${ }^{23}$ He glosses Phares as 'rozdele(n)' and Zara as 'vschodjaščij a(b)o vschodnij'. The story of the birth of these twins and how they came to be given their names is found in the 38th chapter of the book of Genesis.

In the last verse of the second chapter of St. Matthew's gospel it is said that Joseph took the Holy Family to Nazareth 'that it might be fulfilled which was said by the prophets: that he shall be called a Nazarene'. The commentary explains that Nazorej of the Church Slavonic text means 'holy, anointed, consecrated'. ${ }^{24}$ Berynda's Lexicon gives a number of equivalents: ${ }^{25}$ 'Nazorej: o(t)lučenyj, a(bo) korunovanyj, a(bo) posvjačenyj', that is, set apart, crowned or consecrated. The parallels are expected, of course, but they allow us to postulate that the compilers of the commentary had access, if not to Berynda's Lexicon, at least to the sources used by him.

In the sermon on the mount Christ condemns the use of insult to one's fellow-man. One of the expressions to be avoided is a Hebrew word, raka. A marginal gloss reads: 'na(z)visko znevaže(n)ja i vzga(r)dy', or, a name indicating disrespect and contempt. ${ }^{26}$ Berynda gives several synonyms for the word: 'porožnij (ukorizny slovo). Zakonoprestupnyj ... igrajuščij ... meta(f): blaze(n), ne(n)dznyj, golota (Uk. holota), gultaj (Uk. hultaj), necnota, lotr i pr[o](č)'..27 Other examples of such glosses are bezrozumnyj for Church Slavonic jurode, in Matt. 5: 22, and paraližom zaražony $(j)$ for Church Slavonic ra(z)slaben 'sick of the palsy'. ${ }^{28}$

Another type of marginal comment is the explanation of a metaphor. John the Baptist gives a dire and colourful warning to the Pharisees and Sadducees. 'Now the axe is laid to the root of the trees. Every tree therefore that doth not yield good fruit shall be cut down and cast into the fire.' The commentator here informs the reader that 'značyt drevom nedajučy $(\mathrm{m})$ ovocu dobrogo, zlych ljudej' ${ }^{29}$ - by the tree which does not bring forth good fruit he means bad people.

The margins also contain aross-references to other passages of scripture. For example, the genealogy at the beginning of St. Matthew's gospel is provided with cross-references to the appropriate books of the Old Testament, where the statements can be checked. Occasionally entries in the margin give title or heading to an episode of the gospel story. At verse 4 of the third chapter of St. Matthew's gospel a marginal note reads: 'Vzor ode(n)ja, pokarmu, vradu Ioanna Krestitelja' ${ }^{30}$ that is, picture of the apparel, diet, and régime of John the Baptist. By the story of the centurion appears the entry 'pochvaljajet věru so(t)nikovu $\mathrm{Ch}$ [risto] $\mathrm{s}^{\prime},{ }^{31}$ that is, Christ praises the faith of the centurion. The story of the Holy Innocents is introduced by the words 'chitrost' i zdrada Irodova's2 - Herod's cunning and treachery. Finally some of the marginal entries indicate the beginning or end of gospel readings for specific feast-days. 


\section{VII}

For the most part the vocalic system of the vernacular material is common East Slavonic, but in the treatment of jat' and the front nasal vowel of Common Slavonic we see the pattern discussed by Victor Swoboda in his excellent review of a recent work by U. V. Aničenka. ${ }^{33}$ Swoboda points out that in the development of these vowels the South Byelorussian and the North Ukrainian dialects agree. For jat' they both have $e$, whereas the South Ukrainian dialects have $i$; from nasal $e$ they have developed oral $e$, as against the regular East Slavonic reflex, which is ja. Examples for the former are not too frequent since the orthography is fairly traditional and the writer continues to use jat' even though it no longer has any specific phonetic value of its own. Occasionally, however, $e$ is substituted for ĕ: bole(z)ni (Psalter, f. 11), prorocech (ibid., 11 v.), rozumen'ja (ibid., 22 v.). In a number of cases such spellings may be attributable to Polish interference. This would appear to be the case with the preposition prez and the prefixes pre-, pred-, e.g. preznačajučy(j) (Introd., f. 2 v.), pre(d)sjavzja(t)ja (Psalter, f. 12 v.). Examples of $e$ from CS $e$ include the reflexive pronoum which regularly appears as se. The present active participles and gerunds of verbs from Leskien's fourth class may have $e$ as the stem vowel instead of the usual East Slavonic $j a$. The traditional spelling is seen in privodjači (Psalter, f. 3 v.), prosjači (ibid., f. 5 v.), the dialectal variant in $k o(n)$ čečy (Psalter, f. $24 \mathrm{v}$.). Another example of $e$ from $e$ is upameta(n)ja (Psalter, f. 22 v.).

Features of the Byelorussian consonantal system which are illustrated by the material include the hardening of the hush consonants and $\dot{r}$. This is clear from numerous spellings which substitute the letters $o, y$ and $a$ for the traditional $e, i$ and ja: preložonyje (Psalter, f. 9 v.), prynaležat' (ibid., f. 10), značyt' (ibid., f. 11). Hardening of $\dot{r}$ may be indicated by the spelling skrydlami (Introd., f. $2 \mathrm{v}$.) or sekretarov (Introd., f. 2), where the sufix might be expected to have a soft consonant, coming as it does from Latin (secret)arius. But, if foreign words are not acceptable evidence, we can point to a word which demonstrates two features of Byelorussian phonology. The word in question consists of the Common Slavonic prefix $u$ - with root -ręd-, which gives rise to Polish urzad and standard East Slavonic urjad. The spelling vradu, gen. sing., (NT, f. 8) reflects the hardening of $r^{\prime}$, a prime feature of Byelorussian, and in an oblique way the vocalisation of preconsonantal $v$, about which Swoboda has some interesting things to say. ${ }^{34}$

Fricative pronunciation of Common Slavonic $g$, another feature of Byelorussian, shared with Ukrainian and the South-Russian dialects, is borne out by the use of the digraph $\mathrm{kg}$ to represent plosive $g$ in words of Polish and West-European origin, e.g. fikgurujučy (Psalter, f. 10). Re-entry of plosive $g$ into the native vocabulary of Byelorussian become possible when a Common Slavonic weak reduced vowel was lost between $k$ and a voiced consonant.

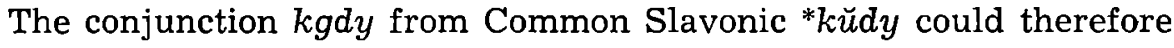


be understood as a native Byelorussian word, although the possibility must be borne in mind that it may be a borrowing from Pol. gdy.

In the spelling of foreign words we note a tendency to indicate the absence of palatalisation of the dental consonants by the use of the letter jery to render Latin $i$, e.g. politycě, dat. sing., (Introd., f. 3), stylem, instr. sing., (ibid., f. 2 v.), dedykovati (ibid., f. 3). This is of course in line with Polish usage. Were it not for the possibility of Polish influence we could confidently take such spellings as indirect evidence for the assibilation of Common Slavonic $t$ and $d$ before front vowels, one of the key consonantal features of the Byelorussian language, which the traditional spelling tends to conceal.

\section{VIII}

The morphology of the noun, pronoun and adjective is for the most part common East Slavonic. In the declension of masculine and neuter nouns we see the encroachment of $u$-stem endings which is carried much further in the Byelorussian and Ukrainian dialects than in Great Russian..$^{35}$ In the genitive singular $-u$ appears in the following examples: ratunku (Psalter, f. 18), priby(t)ku (ibid., f. 20). The dative singular is particularly frequent in the preface and dedication. Here we find jep(i)s(ko)povi, pastyrovi, světovi (Introd., f. 2), archijereovi (ibid., f. 2 v.), Moiseovi, mirovi, sukcessorovi, stroitelevi, o(t)cevi, učitelevi, opekunovi (ibid., f. 3 v.), testamentovi (ibid., f. 5). Note that the ending -ovi/-evi is mostly found with personal nouns but is not confined to them. The writer is sometimes in doubt, as when he has the forms světu and svétovi in close proximity on the same page (Introd., f. 2). The confusion goes back to a much earlier period: synu and synovi are found in the same paragraph of the Russkaja Pravda in the Novgorod Kormčaja Kniga of 1282. ${ }^{36}$ The noun syn is an old $u$-stem so that synu is the innovation here, probably introduced by a careless copyist. In the case of the introduction to the Kucieina New Testament and Psalter one suspects that stylistic or prosodic factors are involved and that a conscious choice was made. The o-stem ending was noted in the following examples from the same passage: panu (Introd., f. 2 v.), zakonopriimcu (ibid., f. 3 v.), sonaslëdniku, cheruvimu, chranitelju, archijereju (ibid., f. 3 v.), pastyru, stroitelju, klejnotu (ibid., f. 4), prikladu (ibid., f. 5 v.).

In the locative singular the $u$-stem nouns had the ending $-u$, as against the front vowel -e of the hard o-stems, with which the $u$-stem nouns were easily confused. As jat by palatalising $k, g$ and $c h$ produced changes in velar stems there was a temptation to substitute the $u$-stem ending which caused no such problems. Examples of this substitution are na poča(t)ku (Introd., f. 5 v.), pri č [e]l[ove]ku, na vidoku (Psalter, f. 24 v.). The ending also spread to the soft-stem neuter nouns, e.g. o pristju, naroženju, $v$ ro(z)širenju, bada(n)ju (Introd., f. 5 v.), pri doskončenju (Psalter, f. 20), pri pos[vja]ščenju (ibid., f. 20 v.). The process is not universally applied to the soft-stem neuter nouns. Side by side with the examples given we find words which preserve the original case-ending -i, e.g. $k r[e]$ ščenii (Introd., 
f. 5), voskr[e](s)[e]nii, vo(z)nesenii (ibid., f.' 5 v.). These latter forms are Church Slavonic which leads us to conclude that the writer found the ending $-i$ more appropriate to the older stratum of the vocabulary. The examples given above with $-u$ occur in words shared with and, in some cases, borrowed from Polish. The phenomenon constitutes a type of morphological bilingualism. It would be interesting to establish the stylistic function of the traditional and innovatory inflections but this is beyond the scope of a short article.

The locative plural of hard o-stem nouns also contained the vowel $\check{e}$ which once again caused palatalisation of velar consonants. The $u$-stem declension provided a convenient solution, for the ending -och, from earlier - $\breve{u c h} \breve{u}$, re-estabłished uniformity of the stem, e.g. $v$ grěchoch (Psalter, f. 22 v.), $v$ ostanko(ch) (ibid., f. $14 \mathrm{v}$.), instead of grěsěch, ostancěch. The ending -ech is also found, e.g. $v$ ty(ch) slove(ch) (Psalter, f. 23 v. - 24).

In verbal morphology one of the most striking features of the language of the commentary is the use of new personal endings in the past tense. These, unlike the endings of the aorist and imperfect tenses, could be attached not only to the past participle in - $l$ (znal-em, etc.), but also to the initial word in a sentence or clause which would frequently be a conjunction, e.g. iže $(m)$ (Psalter, f. 12) or a pronoun, e.g. jam ... movil (ibid., f. 19). In Byelorussian this innovation follows the practice of Polish. Further afield it recalls the relative morphological freedom of the Turkic and other agglutinative languages. Other examples are: spolkovale $(m)$ (Psalter, f. 18), udale(m)sja na pokutu (ibid., f. 23), $k g d y(m)$ chote(l) (ibid., f. 22 v.).

A second striking feature of verbal morphology found in the commentary is the reflexive verbal noun. The flight of the Holy Family to Egypt is referred to as uchile(n)ese (NT, f. 6 v.), which may be compared with Pol. uchilenie się, in a rough translation 'removal of oneself'. In Lithuanian the reflexive pronoun is even incorporated into the word between prefix and root. Išsigelbejimas 'escape' consists of prefix $i \check{s}_{-}+-$si-, the reflexive pronoun, + gelbejimas, the verbal noun from gelbeti 'to save'. The Slavonic languages which have the reflexive noun do not go so far as this, but a somewhat similar formation may be seen in pre(d)sjavzja(t)ja (Psalter, f. 12 v.) 'undertaking', an adaptation of Pol. przedsięwzięcie.

\section{IX}

It is not easy to find specifically Byelorussian features of phonology or morphology, since the orthography in the main follows traditional or etymological principles. Thus we look in vain for evidence for the reduction of unstressed vowels. But we need only call to mind the orthography of modern standard English or Russian to realise that changes in the pronunciation of unstressed vowels need not be reflected in the spelling. As we have seen there is direct and indirect evidence for the hardening of the hush sibilants and $r^{\prime}$, 
for the fricative pronunciation of CS $g$. To these we may add a prime feature of Byelorussian morphology of which one example has so far been noted. This is the omission of epenthetic $n$ between preposition and third person pronoun: $n a i(\mathrm{ch})$ (Psalter, f. $9 \mathrm{v}$.). The interrogative pronouns of Common Slavonic * ${ }^{\circ} b t o$ and ${ }^{*} k u$ to appear in their Byelorussian guise with dissimilation of consonants after the loss of the reduced vowels: što (Psalter, f. 14), nichto (Introd., 4 v.). Also to be noted is the verbal form chočut (Introd., f. $5 \mathrm{v}$.) although the traditional orthography here conceals the possible assibilation of the final dental.

While the language of the commentary is basically East Slavonic there is a strong admixture of Polish features which are frequently but not always retained in lexical Polonisms. Virtually the full gamut of Polish phonology is brought into play. Among common West Slavonic characteristics are here attested: the reflex of CS ch by the Third Slavonic Palatalisation - WS hush consonant $\check{s}$ against ES s, e.g. ovšem (NT, f. 11 v.), všeljakoi (ibid.), retention of dental plosive in CS -dl-, e.g. bydljačogo 'Psalter, f. $22 \mathrm{v}$.); metathesis of the Polish type where East Slavonic has pleophony from CS medial liquid diphthongs, e.g. prevrotny $(m)$ (Psalter, f. 12); krolem (ibid., f. 13 v.); preznačajučy(j) (Introd., f. 2 v.); potrebujut (ibid.). Praca (Introd., f. 2 v.) is a Czech form transmitted via Polish; vladarstvo (Psalter, f. 11) owes its form to Czech influences on Polish, or may be a 'false Church Slavonicism' modelled on Pol. wtodarstwo. The West Slavonic reflex of CS $g t^{\prime}$ is seen in mocju (Psalter, f. 12), while the East Slavonic form occurs in the derivative pomoc (Psalter, f. 7 v.). ${ }^{37}$ The Polish treatment of CS $d j$ is seen in vladza (Psalter, f. 12 v.) from Pol władza in which the root has Czech vocalism. West Slavonic initial $j u$ - and $j e-$ as against East Slavonic $u$ - and o- occur in $j u \check{z}$ (Introd., f. 1 v.) and jednak (ibid., f. 2 v.). There are frequent examples of Polish $e$ from a CS back reduced vowel in a strong position, where East Slavonic has o, e.g. vedlug (Introd., f. 2 v.), ve(s)tche(n)e (Psalter, f. 2), statečnost' (ibid., f. 12), tedy (Introd., f. 3), zemdlony $(j)$ (NT, f. 100), preč (NT, f. 11 v.). There are occasional. Polonisms in which the nasal vowels of Polish are rendered by $e$ or o $+n$, e.g. poneko(n)d (Introd., f. 2 v.). Typical Polish reflexes of CS vocalic $l$ are seen in vedlug (Introd,. f. 2 v.) and movit (ibid.). Forms

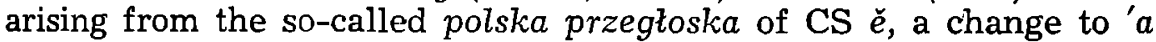
which operates before hard dental consonants, are presljadova(n)ju (Psalter, f. 30) and cale (Introd., f. 1 v.).

Syntactic features attributable to Polish influence are the usage of $\check{z} e$ and by to mean 'since, that' and 'so that' respectively; the conjunctions bověm and ponevaž (Introd., f. 2 v.), ne žeby (NT, f. 8 v.); the pluperfect formation $u m y(s) l i(l)$ by $(l)$ (NT, f. v.); new personal endings in the past tenses; position of these endings in the sentence; various constructions with prepositions, e.g. $z a$ panova(n)ja Tiverija krola, 'in the reign of King Tiberius'.

Some of the lexical Polonisms exhibit features of phonology which establish their origin, e.g. obfitosti (Psalter, f. 13), pristju (ibid.), ufnost(') (Psalter, f. 13 v.). The substitution of East Slavonic phonetic 
equivalents sometimes obscures the picture, e.g. oboroncy, dat. sing., (Introd., f. 3 v.) with -boron- for Pol. -bron-; potužnost' (Psalter, f. 14) with -u- for a Polish nasal vowel; čužoložstva (Psalter, f. 22) with $\check{c}$ - and $-\check{z}$ - against Polish $c$ - and $-d z$-. In such cases the chronology of the Polish and Byelorussian words must be adduced as evidence and the present state of historical lexicography of the East Slavonic languages does not always allow a fair judgment to be made. ${ }^{38}$

Latin words sometimes appear with the minimum of adaptation, e.g. interpretatora, gen. sing., (Introd., f. 2 v.). Other show various modifications of phonology or morphology which usually reflect passage through Polish, e.g. ofjarovati (Introd., f. 2 v.), repreze(n)tovat(') (ibid., f. 2), dedykovati (ibid., f. 3).

Syntactic features of the commentary suggest the writer's dependence on Latin models. His sentence order in the headings to psalms or chapters of the New Testament remorselessly relegates the verb to the end of sentence or paragraph. The reader who is used to English sentence order, which is also the regular means of expression used by the Slavs when they are not exposed to Latin or German influences, is left gasping for air before he reaches the end.

As an example we may take the heading to Psalm no. 12. This reads: ' $O$ ul'žzene gnevu i strofova(n)ja $B$ [o]ž[e]go z prelože(n)em slabosti svoje privodjači sm[e]rt' i sud strašnyj na pamjat', i o pomoč prosit'. A literal translation of this would be - 'for a tempering of God's wrath and chastisement with the excuse of his weakness, bringing death and judgment day to mind, and for assistance he (the psalmist) prays'. In general the style and syntax suggest that the author of the commentary not only had himself a good knowledge of Latin, but could expect the same of his readers.

\section{$\mathrm{X}$}

One interesting aspect of the Kucieina New Testament and Psalter of 1652 is its relationship to the Psalter published at Jeŭje in 1611. Je. F. Karskij's work on 16th-century translations of the Book of Psalms gives two quotations from the commentary of the Jeŭje Psalter. ${ }^{39}$ These are identical with the same passages in the Kucieina Psalter of 1652, and suggest that the latter, like other books from the Kucieina press, was a reprinting of a book earlier printed elsewhere.

On a recent visit to Poland I consulted in the Jagiellonian Library in Cracow a copy of a psalter with commentary which, according to the catalogue of the early printed books department, was printed at Vilna in or about 1630 . I was unable to compare thoroughly and at length the text of this with my notes from the Kucieina Psalter. The Cracow copy is badly damaged and has lost many of the outer pages, including the title page and introduction - if indeed there was an introduction to this edition. However, it was obvious from the limited comparison I was able to carry out that the text of this commentary is the same as that of the Kucieina Psalter. The only differences observed were in the accentuation. 
All this raises the interesting question of the authorship of the commentary. It appears that the writer may have been someone associated with the Vilna and Jeŭje printing presses. One of the most likely candidates might therefore be, as Fr. Alexander Nadson has pointed out to me, Leontij Karpovič, or possible Meletij Smotryckij. Without access to the earlier 16th-century Byelorussian psalters one cannot decide the question of the original text. When that problem is solved it may be possible to identify the author by a comparison with the known work of the suspects.

\section{FOOTNOTES}

* This article is a printed version of a paper read as part of the course in Byelorussian Culture held during the year 1973-4. The examples are given in a simplified transliteration, omitting the letter jer (hard sign), and not distinguishing the various shapes of the letters $e, i, o, u, j a$. Supralinear letters are given in rounded brackets; letters omitted from abbreviations in square ones. Accents and pajerki are not given. The letter $\Gamma$ is transliterated as $g$, although it is clear that it denoted a fricative consonan't. The Cyrillic of the three long texts given in the article and appendix is also simplified for technical reasons, but here the jers and jat' are retained, and one or two peculiarities are commented on in the footnotes.

1. I. Karatajev, Opisanije slavjano-russkich knig napečatannych kirillovskimi bukvami, I, St. Petersburg, 1883, no. 684.

2. The only other copy I have seen is in the Biblioteka Narodowa, Warsaw; this is not as well preserved as the Skaryna Library copy.

3. References will be to folio number of Introduction (Introd.), Psalier or New Testament (NT).

4. A P. Lopuchin, Pravoslavnaja bogoslovskaja enciklopedija. XII, St. Petersburg, 1911, p. 184; Polnyj pravoslavnyj bogoslovskij enciklopedijskij slovar', I-II, St. Petersburg, no date, cols. 1389-90.

5. See Ukrajins'ki pys'mennyky, I, ed. L. Je. Machnovec', Kiev, 1960, pp. 568-9. Trucevič wrote prefaces for the following books published by the Kucieina press: Brašno duchovnoje (1639); Trifologion ili cvetoslov (1647); Dioptra ili zercalo $i$ izobraženije života vo mire sem čelovečeskago, by Abbot Vitalij of Dubno (1651 and 1654); New Testament and Psalter (1652); Leksikon slavenorosskij ... Pamvoju Beryndoju ... zgromaženyj (1653). See also I. U. Budovič, Slovar' russkoj, ukrainskoj $i$ belorusskoj pis'mennosti $i$ literatury do XVIII veka, Moscow, 1962, p. 120. The preface to the second edition of Berynda's Lexicon may be seen in Leksykon slovenoros'kyj Pamvy Beryndy, ed. V. V. Nimčuk, Kiev, 1961, pp. 248-50.

6. Filaret, Obzor russkoj duchovnoj literatury, I, Kharkov, 1859, p. 280. F. A. Brokgaus and I. A. Jefron, Enciklopedičeskij slovar', XIIIa, St. Petersburg, 1894 , p. 741 , has a short note, s. v. 'Ioil'.

7. 'Az poslušanije moje $\mathrm{k}$ pastyrju i po smerti sochranju', Filaret, loc. cit.

8. L. I. Denisov, Pravoslavnyje monastyri rossijskoj imperii, Moscow, 1908, pp. 582-3.

9. Denisov, loc. cit.

10. Russkaja istoričeskaja biblioteka, IV, St. Petersburg, 1878, cols. 54-5. Afanasij had been given the task of raising money for the restoration of the Orthodox church at Kupjatiči near Pinsk, and a voice from Heaven had announced to him that the Tsar would assist with this project.

11. Penultimate stress in some of these examples could be the result of Polish interference.

12. The word klejnot could mean not only 'jewel' but also 'heraldic bearings' and 'device worn on a helmet, characteristic crest of a knight's helmet', see F. Sławski, Slownik etymologiczny języka polskiego, II, Cracow, 195865, p. 202. The poem exploits this polysemy which evades translation. 
13. The word occurs as an entry in the Latin-Slavonic dictionary of Jepifanij Slavineckij: 'triones bi (sic! - presumably for boves); voli oruščii, Voz n[e]b[e]sni(j)', v. Leksykon latyns'kyj Je. Slavinec'koho, ed. V. V'. Nimčuk, Kiev, 1973, p. 403. The English quotations are from the Oxford English Dictionary.

14. Since Byelorussian does not have phonemic distinctions of quantity the metrical pattern of Latin -wu $-v$ is reinterpreted in 'tonic terms as a sequence of 1 stressed, 3 unstressed, 1 stressed, 1 unstressed syllable.

15. The other examples are: g[o]s[pó]dnja komparújut; uvaženja potrebújut; tajémnicy naléžat; ukrasí tja krasotóju.

16. NT, f. 8.

17. Ibid.

18. Ibid.

19. NT, f. $6 \mathrm{v}$.

20. Psalter, f. 1v.

21. Psalter, f. 3v.

22. NT, f. 5 .

23. Berynda, op. cit., col. 467, lines 8-10, and 404, 22-23.

24. NT, f. 7v. The Church Slavonic text here has 'Nazarej'; the marginal note reads: 'Nazorej svjatyj ... pomazany $(j)$ posvečony $(j)$ značy $(t)$ sja'.

25. Op. cit., col. 438, lines 6-8.

26. NT, f. 11.

27. Op. cit., col. 428, lines 13-18.

28. NT, f. $18 \mathrm{v}$.

29. NT, f. 8.

30. Ibid.

31. NT, f. $16 \mathrm{v}$.

32. NT, f, $6 \mathrm{v}$.

33. Journal of Byelorussian Studies, II, London, 1971, pp. 310-5.

34. Ibid., p. 313.

35. For an exhaustive discussion of the problem, see F. P. Filin, Proischoždenije russkogo, ukrainskogo $i$ belorusskogo jazykov, Leningrad, 1972, pp. 366-410. Filin admits the possibility of Polish influences on Ukrainian in the case of the dative singular ending -ovi.

36. S. P. Obnorskij and S. G. Barchudarov, Chrestomatija po istorii russkogo jazyka, I, 2nd ed., Moscow, 1952, p. 57.

37. On consonantal variations in derivatives of this root see $H$. Leeming, 'Form and function in Mianžynski's "Romance of Alexander"', Journal of Byelorussian Studies, II, London, 1971, pp. 267-70.

38. Filin, op. cit., pp. 621-4.

39. Je. F. Karskij, Zapadnorusskije perevody Psaltyri $v$ XV-XVI vekach, Warsaw, 1896, pp. 43-4. 
APPENDIX A: The dedication

ПРЕОСВЯЩЕННОМУ ЕГО М[и]Л[о](С)ТИ Г[о](С)[по]Д[и]НУ О(Т)ЦУ ИОСИФОВИ ГОРБАЦКОМУ. М[и]л[о](с)[тю] Б[о]жиею Право(с)[лавному] Еп[и](с)[ко]пови Витебскому, Мстиславскому, Оршанскому и Могилевскому. Намъстникови в Велико(м) Кн[я](з)стве Литовско(м), Митрополии Киевское. и Екса(р)шескому Фрону Ко(н)ста(н)тинопо(л)[скому]: $\quad$ Г[о](с)[по]д[и]ну О(т)цу и Пастырови Н[а]шему Здравия, До(л)годе(н)ствия и спасения зычьщмъ.

Розумъ людъский освъчаючие ${ }^{1}$ таемницы, през Секретаровъ $\mathrm{H}[\mathrm{e}]-$ б[е](c)ныхъ свътови до трытунованя ${ }^{2}$ поданые, хотячи свъту репрезе(н)товат(ь): преосвященый $[П а н] \mathrm{e}^{3}$ и Пастыру нашъ пришло на(м) на памя(т) нъкоторы(х) Писма с[вя]таго Б[о]гослово(в) здане: же Архиереовъ до оныхъ Херувимовъ которые скрыдлами своими, осъняли киотъ ${ }^{4}$ завъта Г[о](c)[по]дня, компаруютъ. На которое ла(т)во напавшы, за речъ слушную розумъемо, теперешнюю малую нашу працу, никому иншому, толко Архиереови, офяровати. Таковые бовъмъ таемницы Па(н)ские. любо понеко(н)дъ здаются, латвым стылемъ, з ка(н)целярии $\mathrm{H}[\mathrm{e}] б[\mathrm{e}](\mathrm{c})$ ное выданые: великого еднакъ уваженя потребують. Аже Херувимъ, Архиерея презначаючы(й), ве(д)лугъ Б[о]гослововъ Писма С[вя]того, ничого иншого незначить, толко исполнение умъе(т)ности, Тобъ Пану и Пастырови нашему, преосвяще(н)ному Архиереови, при Досконалои Мудрости, и умъетности, таковыи таемницы належатъ. Поневажъ и $\mathrm{X}[$ ристо] $Г$ Гоo](c)[по]дь, таковыми Архиереовъ хотячи ме(т), у С[вятого] Ион(н)на Еу[анге]листы такъ о нихъ мовить: и овца гласъ его слыпатъ. ${ }^{5}$ Частого вправдъ поучения потребуютъ овца. Потребуетъ и наша теперешняя праца, учителя и интерпретатора, и, поневажъ Пастыръ Св[я]тый ${ }^{6}$ овца тлашаеть по имени, и овца по нем идутъ. ${ }^{7}$ Теды и намъ в Смире(н)номъ Послушании мешкаючи(м) при Ц[е]ркви Б[о]гоявлений: Б[о]гомъ явленный, през Секретаровъ $\mathrm{H}[\mathrm{e}] б[\mathrm{e}](\mathrm{c})$ ньх тае(м)ницы, преос[вя]щенству Твоему, достойнь приносити, и усердно дедыковати, подобаетъ. Если бовъмъ, в Свътовой Выкопомной Политыць, Ораторомъ и ВЪръшописцом, науками Свътовыми розум свой поляруючимъ, опекуновъ обирати, потребная речъ здалася. Которыхъ они не толко своими енкомиами, широко описуючи, непамяти затлумитъ недопустили, овшем несмерте(л)ною, ачъ про(ж)ною славою приоздобили: Далеко барзей нам смире(н)ным, Свђтилу о(т) Свђтлости неугасаючой ос[вя]щенному, по(д)лугъ словъ самое незаходимое Свътлости: Вы есте свътъ миру и далей: невжигаютъ свђтилникъ, и поставляют его по(д) спудомъ, но насвьщницъ, и свьтитъ всим иже вохраминъ суть, ясности не уволокати: овшемъ Несмертельной Славъ, несмертельности додавати. Данныя же з Шафарни $\mathrm{H}[\mathrm{e}] б[\mathrm{e}](\mathrm{c})$ ное, Преос[вя]щенству твоему тала(н)ты, ширити и умножати, и свъту объясняти належитъ. А яко Самому толко законоприъмъцу Моисеови, ${ }^{8}$ на Скрижалехъ Законъ о(т) Б[о]га писаный, мирови проповъдати и обясняти Повърено: При- 
шедъ же Моисей, ${ }^{8}$ возва вся Старца людские и рече, и исповьда имъ вся словеса си, яже завъща имъ Б[о]гъ. Такъ и Б[о]жественныя благодати новый законъ, Б[о]жественным АП[о](c)[то]ломъ вовъренный, сукъцессорови и сонасльднику ихъ, Херувиму исполненному умъетности, законоприимцу Б[о]жественньц Благодати, непорочныя Ц[е]ркви Строителеви, Православия хранителю, и жарливому оборонцы, о(т) сыновъ в Д[у]ху О(т)цеви, о(т) учениковъ учителеви, о(т) клиентовъ Опекунови, Тобъ Преос[вя]щенному Архиерею, и Пастырови нашему приносити на(м) подобаетъ. Дотого, же и Ц[е]рковъ наша Православная, видячи труды працы и подвиги Преос[вя]щенства твоего, такъ в науць слова истины, яко тежъ въ оборонь Бл[а]гочестия, Помноженю и укрьпленю истинное Вьры, на мьйсцахъ публичныхъ помного кр[от] ${ }^{6}$ показаные: Внагороду, Пастораломъ ${ }^{9}$ Б[о]годанное ти Паствы, во овчарни своей достойнь Преосвьтлое Преос[вя]щенство твое, приоздобила. Оде(ж)дою веселия одњя тя, яко жениху возложи ти вънецъ, и яко невьсту украси тя красотою. Для ты(м) свьтлейшого Бл[а]гольпия Преос[вя]щенства твоего: мы нищьп духо(м), Новую Свътло(ст), Ма(р)гаритъ Б[о]ж[е](с)тве(н)ныя Новыя Бл[а]г[о](д) [а]ти, о(т) Архипастыра X[рист]а Б[о]га, ненаскрыжале(х), але на с[е]p(д)цахъ Ап[о](c)[то]лъ и Еу[ан](г)[е]листъ, ${ }^{8}$ писаный: Тобь Пастыру и Строителю новыя Бл[а]г[о](д)[а]ти, о(т) тебе повеле(н)ная нами, мирови хотячи обяснити, и ново типо(м) ${ }^{8}$ убогое працы нашое, повъре(н)но(й) ти о(т) Б[о]га Паствъ, по(д) тытуло(м) Преос[вя]щенства твоего, репрезе(н)товати: Сего нового Тестаме(н)ту, Преос[вя]щенство твое, екзекуторо(м) чинимо. Такового бове(м) Тестаме(н)тъ екзекутора потребуетъ, который бы знемовячи(х) оного лите(p), вживый оборочалъ голосъ. Потребуетъ и того, абы проти(в)никомъ Тестаме(н)ту, екзекуто(р) его моцно ставалъ. Длятого и мы о(т) Архипастыра, Пастырови вручаем, Абы Клейноту Ц[е]ркви Православной да(н)ному нихто шкодити не мо(г). Прийми прето о(т) на(с) убогих, Преос[вя]щенный Пастыру, тую малую нашу працу, мы бове(м) Овца суще Паствы твоея, в Бл[а]гословение Преос[вя]щенства твоего, совсими Православно Хр[и]столюбивыми чытателми, сего нового Завьта: смиренно вручаемся.

\author{
Вашей С[вя]тите(л)ской м[и]л[о](с)ти \\ $\Gamma[0](\mathrm{c})[п о] д[и]$ на о(т)ца и Пастыра нашего \\ зьгливыи послушницы. \\ и М[о]л[и]твенницы пр[и](с)ныи, \\ Иеромо[на](х) ИОИЛЬ Труцеви(ч) Игуме(н) \\ Совсею в X[рист]њ братиею Мона(с)ты \\ ра Общежителна(г) Кутеи(н)ско(т).
}

Wishing to present to the world those mysteries which enlighten human reason, the mysteries handed down to this world by the secretaries of Heaven for our ponderation, we recalled to mind, most Holy Lord and Pastor, the opinion of certain scriptural theologians, whereby they compare Archbishops to those Cherubim who used to shield with wings the Ark of the Lord's Testament. Having with no difficulty chanced upon this thought, we now regard it as only right 
and proper to offer this present little work of ours to none other than our Archbishop. For such Divine mysteries, while they occasionally appear to be published in an easy style by the Secretariate of Heaven, still demand great attention.

And, since the Cherubim, who according to scriptural theologians personify the Archbishops of the Church, signify naught else but the consummation of art, then, Most Holy Archbishop, such mysteries are your proper concern in view of your perfect wisdom and art, Our Pastor and Lord. For even Christ, Our Lord, wishing to have archbishops of this kind, speaks thus of them in the Gospel of St. John: 'And the sheep hear his voice'.

In very truth the flock requires frequent instruction. So too this present work of ours requires an instructor and expositor, and, since the Holy Pastor summons his sheep by name and they follow Him, so also it befits us who dwell in humble obedience at the Church of God's Manifestation duly to offer and eagerly to dedicate to Your Exceeding Holiness these mysteries manifested by God through the agency of the Heavenly Secretaries.

For if in the immemorial polities of this world great orators and poets of an intelligence refined by secular learning conceived it as essential to choose a patron, whom not only would they portray in lengthy encomia lest he be buried in oblivion, but even bedeck with an immortal, though empty fame, how much more fitting is it for us in due humility, bearing in mind the words of that Light which never sets - 'You are the light of the world', and further - 'Neither do men light a candle and put it under a bushel, but upon a candlestick, that it may shine to all that are in the house', not to disparage the brightness of this Luminary consecrated by an unwaning Splendour, but to add immortality to an Undying Fame, and to proclaim to the world at large, to publish and propagate those talents bestowed on Your Exceeding Holiness by the Heavenly Dispensator.

And just as Moses the Law-giver alone was entrusted with the preachment and exposition of the Law written by God on the Tablets, - 'Moses came and summoned all the elders of the people and told them all the words which God had commanded him' - now also it behoves us to offer to you, our Most Holy Archbishop and Pastor, successor and co-heir of the Apostles, Cherub of consummate wisdom, law-keeper of Divine Grace, Administrator of the Church immaculate, custodian and zealous champion of Orthodoxy, this, the new testament of Divine grace entrusted to God's Apostles, presented by your children to their Father Confessor, by your disciples to their teacher, by your clients to their Patron.

Furthermore, our Orthodox Church, seeing your labours, efforts and endeavours both on behalf of the doctrine of the word of truth and in the defence of Piety, as Your Exceeding Holiness strove to propagate and fortify the true Faith on numerous occasions in public places, in reward conferred upon Your Most Radiant Exceeding Holiness a crozier, due token of your God-given pastoral charge over 
your flock. You have been arrayed in the garments of joy, crowned like a bridegroom and clad in beauty like a bride.

To further enhance the magnificence of Your Exceeding Holiness we, poor in spirit, present to You, Pastor and Administrator of the new Grace, this New Splendour, this Pearl of God's New Grace, written by Christ, Our God and Chief Pastor, not on tablets but in the hearts of the Apostles and Evangelists, and wishing to publish to the world at your bidding and to introduce this newly printed modest work of ours to the flock entrusted to you by God under the auspices of Your Exceeding Holiness, we now appoint you executor of this new Testament.

For the Testament requires an executor who can transform its dumb letters into living speech. Wherefore, in order that no man may harm this Jewel granted to the Orthodox Church, we now commend it from the Chief Pastor to our own Pastor. Accept therefore from your poor folk, Most Holy Pastor, this little work of ours, for we who are the flock of your Pasture humbly commend ourselves to the Benediction of Your Exceeding Holiness, together with all the devout Orthodox Christian readers of this new Testament.

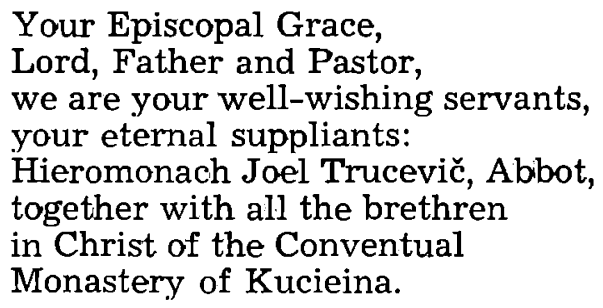

APPENDIX B: Preface to the reader

\section{ПРЕДМОВА ДО ЧИТЕЛНИКА}

Православия твоего, Православный Читателю: жро(д)ло и фундамент, в по(л)зу д[у]шевную з Типографии ${ }^{10}$ нашое, пре(з) друкъ свъту подаемо. Таковои надьи будучи: ижъ гды, 11 тому новому Тестаме(н)тови, пи(л)но припатроватися, и оного врукахъ часто пъстовати будешъ; "з Хр[и](с)то(м) Сп[а]сителе(м) себе розмовляти латво зрозумъешъ. Абовъмъ, вне(м) суть описана, вся его Бо(з)кая о сп[а](c)[е]нии нашемъ, таемница. Якото о м[и]л[о](с)рд[н]о(м), звъковъ пожаданомъ, пристю его на зе(м)лю, опредивно(м) Нароженю, о Кр[е]щении славном о чудах неслыханы(х): и см[е]рти его неви(н)ной, для збавеня рожаю лю(д)ского, доброво(л)не по(д)нятой, о тридневно(м) изм[е]ртвых Воскр[е](с)[е]нии: и хвалебно(м) на Н[е]бо Во(з)несении, о второ(м) настрашный д[е]нь судный пристю: и о ины(х), ку науце и прикладу до збавеня н[a]- 
шего, справа(х). Ку тому те(ж), Гистория дълъ и крвавыхъ працъ С[вя]тыхъ Ап[о](с)[то]ло(в), вро(з)ширеню С[вя](т)[ого] Еу[ан](г)[е]лия, и послания або листы ихъ, до ро(з)ны(х) краинъ писаныи. А прико(н)цы, о(т)кровения С[вя]т(о)го Иоа(н)на, страшны(х) таемниц по(л)ным. невспоминаемъ псалмо(в), и исповьдателных плачевны(x) м[о]л[и]твъ, Царя и Пр(о)р[о]ка, Д[а]в[ы]да на само(м) поча(т)ку положены(x). Которую то книгу, втаемница(х) Б[о]зски(х) обфитуючую; им пи(л)ней читати будешъ, ты(м) бо(л)шую соло(д)кость в с[е]p(д)цу своем учуеш, Коль сладка (бовъ(м): мови(т) ц[њ](c)[a]рствуючий Пр(о)р[о]къ) гортани моему словеса твоя; паче меда устомъ моимъ. И сам Х[ристо]с Сп[а]сите(л) наш, в пи(л)нымъ Писма С[вя]т[о]го бада(н)ю, живот въчньй указуетъ: гды ${ }^{11}$ мови(л): Испытайте писаний яко вы мните внихъ имьти жывотъ въчный, а поневаж так великий, на(д) вси н[а]ши забавы ест важньйший пожитокъ, вписмь С[вя]томъ: зачы(м) пилная того е(ст) потреба, абы(с) в оное 3 великою прильжностю завше вникалъ и уважалъ: и ведлугъ того вси свои корыговалъ ${ }^{11}$ справы и учи(н)ки: абысь в евъдомости оного, в темности якие ци(м)мерийские ${ }^{8}$ незаблудилъ. А гды ${ }^{11}$ читанемъ и уважанемъ Писма C[вя]т[о]го, забавлятися зпилностю будешъ: барзо ла(т)во и сна(д)но, нибы пре(з) перспективу якую, вси стежки шкодливые, та(к)же и пожите(ч)ные до ц[а]p(c)тва, тобъ вдьди(ч)ство объцаного, ведучые выбачишъ. которого и мы тобъ вседушне сприяючи, тую нашу працу по(д)нялисмо: тыже прильжно чтуще, и о нашемъ невъжествии помоли ся. Здравствуй о Г[о](c)[по]дњ.

\section{PREFACE TO THE READER}

For your spiritual benefit, Orthodox Reader, we bring into the light from our Press the printed source and foundation of your Orthodoxy, cherishing the hope that when you shall keenly examine this New Testament, holding it frequently and tenderly in your hands, you shall readily understand that you are conversing with Christ, your Saviour. For here are described all the Divine mysteries of our salvation, the long-awaited, merciful advent upon the earth, the miraculous Birth, the glorious Baptism, the wonderful miracles, His innocent death willingly undergone for the redemption, Resurrection from the dead after three days, glorious Asension into Heaven, His second coming at the awesome day of judgment, and other matters which may help us to learn and find a model for our salvation.

Furthermore, the history of the labours and bloody toils of the Holy Apostles for the propagation of the Holy Gospel, and their epistles or letters written to various lands, and finally the revelations of St. John, full of terrible mysteries, to say nothing of the psalms and confessorial laments of the King and Prophet David which appear at the beginning of the book. 
The more diligently you read this book, so rich in Divine secrets, the greater consolation you shall feel at heart. For the King and Prophet himself says: 'How sweet are Thy words in my throat; sweeter than honey in my mouth'. And even Christ, our Saviour, Himself indicates the everlasting life which may come from a diligent examination of the Holy Scriptures when he says: 'Examine the scriptures since you believe you may find eternal life in them'. And because there is such benefit to be found in the holy Scriptures, far beyond that given by all our pastimes, there is therefore an urgent need for you to meditate upon and ponder these things with great attention at all times, and to correct all your affairs and actions in accordance with them, lest through ignorance you should blunder into some Cimmerian gloom. And if you diligently spend your time reading and meditating upon the Holy Scriptures, then very easily and without effort you shall have a clear view in perspective of all the harmful paths, and also all the beneficial ones leading to that kingdom promised as your inheritance. Wishing with all our hearts to assist you in this we undertook this labour of ours. As you read it with due attention, say a prayer also for our ignorance. Enjoy good health in the Lord.

\section{FOOTNOTES TO THE APPENDIX}

1. An alternative is given in the margin, viz. ostrjačije 'which sharpen'.

2. A rare word; cf. 'trutination' in 17th-century English. It is from the postclassical La'tin verbal noun trutinatio of trutinor 'I weigh', based on trutina 'balance', a loanword from Greek $\tau \rho v \tau \alpha \nu \eta$. The Latin verb occurs in Slavineckij's dictionary where it is translated by razsuždaju, važu, vešu. Metathesis of the vowels in the first two syllables is probably accidental although frequency of initial tri- in Latin and confusion with the Slavonic numeral may have played a role.

3. The first three letters are not clear.

4. Spelt with ižica and ot; the spelling is historically incorrect since the Greek source had iota: $\kappa \iota \beta \omega$ ros. Berynda admits this as an alternative to кивоть, see op. cit., col. 422, line 11.

5. The quotations are given in smaller type.

6. Not clear.

7. It is not clear whether this full stop in fact marks the end of a sen'tence. I take it that the five preceding words are part of the subordinate clause introduced by ponevaž, and that therefore the sentence does not end a't idut.

8. Spelt with ižica.

9. Cf. Pol. pastorat, Lat. pastorale.

10. Spelt with ižica and plosive $g(r)$.

11. Spelt with plosive $g$. 